\title{
Zarządzanie więziennictwem w Królestwie Polskim (1867-1918) na przykładzie guberni lubelskiej
}

Administering the prison system in the Polish Kingdom (1867-1918) for example Lublin governorate

\section{STRESZCZENIE:}

Więziennictwo w XIX wieku było jednym z wyznaczników postępu cywilizacyjnego państwa, jednak w Królestwie Polskim po powstaniu styczniowym zaczęto wprowadzać wzorce rosyjskie. Dodatkowym elementem pogarszającym jakość resortu był nacisk na rusyfikację personelu. Artykuł analizuje rolę poszczególnych organów władzy w zarządzaniu systemem penitencjarnym i jego elementami. Kluczową komórką był referat więzienny Rządu Gubernialnego, który był częścią aparatu wykonawczego organu kolegialnego w postaci Rządu Gubernialnego. Tylko w guberni warszawskiej powołano wydział więzienny jako realizację inspekcji więziennej.

Słowa kluczowe: więziennictwo, Królestwo Polskie, Imperium Rosyjskie, gubernia lubelska, rząd gubernialny, zarząd powiatowy

Więziennictwo w XIX wieku było jednym z wyznaczników postępu cywilizacyjnego państwa. W Europie i USA przemiany rozpoczęły się już w pierwszej połowie XIX wieku. Także w Księstwie Warszawskim Julian Ursyn Niemcewicz zapoczątkował modernizację tego sektora ${ }^{1}$. Dekretem o organizacji ministerstw z 7 III 1808 r. ustalono, że wykonanie kar mia-

${ }^{1}$ S. Walczak, Prawo penitencjarne. Zarys systemu, Warszawa 1972, s. 238-239; T. Demidowicz, Z dziejów polskiej myśli penitencjarnej. Julian Ursyn Niemcewicz (1758-1841) i jego poglądy na temat więziennictwa, "Przegląd Więziennictwa Polskiego" 2005, nr 49, s. 206; J. Czołgoszewski, Więziennictwo Księstwa Warszawskiego, „Przegląd Więziennictwa Polskiego" 2010, nr 69, s. 129. 
ły nadzorować sądy, a zarządzanie więzieniami powierzono władzom administracyjnym ${ }^{2}$.

Jednak w Królestwie Polskim stopniowo zaczęły być wprowadzane wzorce rosyjskie. Nastąpiło to szczególnie po upadku powstania styczniowego. W 1867 r. weszła w życie reforma ogólnej administracji terenowej, która zmieniła nie tyle nomenklaturę administracyjną ile ustrój administracji i pozycję organów, a zwłaszcza gubernatora, rządu gubernialnego, naczelnika powiatowego, zarządu powiatowego i, co ciekawe, konstytuowała odmiennie od Rosji - wicegubernatora. Najważniejszą zmianą było ustalenie dominacji gubernatora jako jednoosobowego organu odpowiedzialnego przede wszystkim za umocnienie panowania rosyjskiego i co za tym idzie - za kontrolowanie aktywności społeczeństwa oraz stosowanie represji.

Z faktów natury prawnej, które wpłynęły na działalność administracji terenowej w dziedzinie więziennictwa, należy wymienić:

1) likwidację Komisji Rządowej Spraw Wewnętrznych w 1868 r. i tym samym podporządkowanie tych kompetencji MSW w Petersburgu;

2) 27 II 1879 r. [tu i dalej: st.st.] utworzenie w MSW Głównego Zarządu Więziennego (GZW) (Главное тюремное управление) przeznaczonego do centralnego zarządzania więziennictwem;

3) ukaz z 21 III 1890 r. Об учреждении губернской тюремной инспекциии, na mocy którego w składzie zaplecza urzędowego prezydiów rządów gubernialnych powstały wydziały więzienne na czele $\mathrm{z}$ gubernialnym inspektorem więziennym, który podlegał GZW, a służbowo gubernatorowi; jednocześnie $\mathrm{w}$ swoich kompetencjach nadano mu pozycję równą wicegubernatorowi (np. kontroli administracji miejsc odosobnienia), zaś gubernator zachował prawo prowadzenia samodzielnej polityki kadrowej w więziennictwie;

4) 13 XII 1895 r. przejście GZW i więziennictwa w Imperium Rosyjskim do resortu sprawiedliwości ${ }^{3}$;

5) 2 V 1894 r. rozciągnięcie na Królestwo rosyjskich przepisów z 1890 r. Inspekcja więzienna została utworzona w Królestwie Polskim, ale w praktyce tylko przy rządzie gubernialnym warszawskim (zob. ilustracja) powstała realna struktura; utworzono tam wydział więzienny na czele z inspektorem (варшавский губернский тюремный инспектор).

Podporządkowanie więziennictwa Królestwa Polskiego MSW w Petersburgu ani jego późniejsze konsekwencje $\mathrm{w}$ istocie nie spowodowały

${ }^{2}$ A. Osoba, Z dziejów polskiej dziewiętnastowiecznej myśli penitencjarnej, „Przegląd Więziennictwa Polskiego" 2001, nr 32-33, s. 102.

${ }^{3}$ Узаконения о присоединении к составы МЮ главного тюремного управления, „Тюремный Вестник" 1896, nr 1. 
kompletnego upodobnienia tej dziedziny do wzorców rosyjskich ${ }^{4}$. O wiele ważniejsze były tu zmiany personalne, a więc tak charakterystyczna dla całej administracji, a szczególnie dla służb mundurowych, depolonizacja. Warszawski gubernialny inspektor więzienny, ze względu na swoją wyjątkowość, otrzymywał z GZW zadania dotyczące całego kraju. Jednak nie oznaczało to żadnych kompetencji decyzyjnych. Inną różnicą w stosunku do Imperium było działanie tam Kolegiów ds. więzień 5 .

Co ważne, w Królestwie nadal obowiązywała instrukcja więzienna sprzed powstania (z 1859 r.) $)^{6}$. Dopiero w 1895 r. zaczęto przygotowywać się do wprowadzenia na tym terenie rosyjskiej ustawy o trzymanych pod strażą z 1857 r. Jednak od razu założono, że do nowych przepisów włączy się te artykuły polskiej instrukcji, które „ze względu na lokalne okoliczności uzna się za konieczne zachować" ${ }^{8}$.

\section{GUBERNATOR, WICEGUBERNATOR I PREZYDIUM RZĄDU GUBERNIALNEGO}

Wśród wielu kompetencji powierzonych administracji gubernialnej znajdowało się także zarządzanie więziennictwem i konwojowaniem więźniów. Co ciekawe, mimo związku z bezpieczeństwem i represywnym charakterem więziennictwa nie włączono go do monokratycznych kompetencji gubernatora, które realizowałby on poprzez swoją kancelarię.

Do kompetencji rządu gubernialnego pod przewodnictwem gubernatora, na mocy art. 34, należało m.in.: zatwierdzanie licytacji na dostawy żywności do więzień, kupowanie ubrań dla więźniów w fabrykach więziennych, zatwierdzanie planów i kosztorysów na budowę budynków więziennych, a pod przewodnictwem wicegubernatora - zatwierdzanie dostawy lekarstw do więzień w miastach gubernialnych. Sprawy więzien-

${ }^{4}$ Dobrze orientuje w aktywności GZW i kierunkach jego polityki, wydany w dwóch tomach, zbiór cyrkularzy, które były podstawowym narzędziem władzy administracyjnej. Zob.: Сборник ициркуляров, изданных по главному тюремному управлению в 1879-1895 гг., cz. 1: 1879-1895, cz. 2: 18961910, С.-Петербург 1911.

${ }^{5}$ Полное Собрание Законов Российской Империи, собрание 2-е, t. 26, nr 25725, Устав Общества попечительного о тюрмах z 7 XI 1851 r.

${ }^{6}$ Instrukcja dla więzień i zakładów karnych Królestwa Polskiego, Warszawa 1859.

${ }^{7}$ Ustawa ta (Устав о содержащихся под стражею) była następnie nowelizowana $\mathrm{w}$ latach 1886, 1890, 1906, 1908 і 1909 - Свод Законов Российской Империи, wyd. 1912 r., t. 14. Drugim kluczowym dla omawianych zagadnień aktem prawnym była Ustawa o zesłańcach (Устав о ссыльных) także z 1857 r. (nowelizowana w 1890 i 1909 r.)

${ }^{8}$ Archiwum Państwowe w Lublinie (APL), Rząd Gubernialny Lubelski (1867-1918) (RGL), sygn. WP III 1895:110, knlb., Warszawski gubernialny inspektor więzienny do Wydziału Wojskowo-Policyjnego Rządu Gubernialnego Lubelskiego z 16 IX 1895 r. 
nictwa na posiedzeniach prezydium rządu gubernialnego referowali kierownicy wydziałów: wojskowo-policyjnego, budowlanego i lekarskiego. Natomiast sprawy konwojowania więźniów skoncentrowano w referacie więziennym (więzienno-transportowym) wchodzącym w skład wydziału wojskowo-policyjnego' ${ }^{9}$ Ten wydział także, poza innymi sprawami, zajmował się właśnie zarządzaniem więzieniami i ich podopiecznymi oraz innymi „podejrzanymi” kategoriami ludzi, jak cudzoziemcy czy włóczę$\mathrm{dzy}^{10}$. Struktura tego wydziału rządu gubernialnego $\mathrm{w}$ Lublinie prawie się nie zmieniła aż do ewakuacji urzędu. Składała się ona z czterech referatów.

Referat III (więzienny) zarządzany był, co znamienne, przez buchaltera, a pracowało $\mathrm{w}$ nim dwóch młodszych pomocników referenta (jeden zwany pomocnikiem buchaltera prowadził korespondencję i księgę kontrolną kar pieniężnych, a drugi księgi rachunkowe) i trzech pracowników kancelaryjnych. ${ }^{11}$

Udało się odtworzyć obsadę stanowiska kierownika tego referatu (buchaltera). Kolejno funkcję tę sprawowało 12 urzędników:

1. Aleksandr Anzelmowicz Roman (1867-1879).

2. Józef Dionisjewicz Jezierski (1878-1884).

3. Jan Michajłowicz Decjusz (1885-1890).

4. Nikołaj Stiepanowicz Jurasow (1990-1894).

5. Archip Andriejewicz Czipak-Gniedoj (1894-1901).

6. Aleksandr Wasiljewicz Walewskij-Lewkowskij (1901-1908).

7. Aleksandr Moisiejewicz Bierieżnickij (1904).

8. Jelefierij Josifowicz Powalczuk (1908-1909).

9. Jakow Dionisjewicz Traulinskij (1909-1910).

10. Lew Serapionowicz Zarembo-Gadziackij (1911).

11. Anton Iwanowicz Bojko (1911-1914).

12. Stiepan Piotrowicz Lipowskij (1914).

Wydział wojskowo-policyjny należał do najwcześniej zrusyfikowanych, a referat więzienny nie był tu wyjątkiem. Jeśli chodzi o personel więziennictwa, panuje opinia, że rekrutowano go z Rosjan ${ }^{12}$, jednak połowa spośród kierowników referatu pochodziła z guberni wołyńskiej i zaledwie jeden z Rosji, z guberni niżnonowgorodzkiej. Pozostali byli miejsco-

${ }^{9}$ APL, RGL (1867-1918), sygn. K 1867:3.

${ }^{10}$ Dziennik Praw Królestwa Polskiego (DPKP), t. 66, Warszawa 1866, Ustawa o zarządzie gubernialnym i powiatowym w guberniach Królestwa Polskiego z 19/31 XII 1866 r., art. 57.

${ }^{11}$ APL, RGL (1867-1918), sygn. osobowe 442; sygn. WP III 1875:125; sygn. WP III 1911:215a; sygn. WP III 1906:302; wraz z wybuchem wojny do referatu dodano jeszcze jednego pomocnika referenta - sygn. K 1914:11.

${ }^{12}$ М. М. Гернет, История цุарской тюрмй, Moskwa 1952, s. 378. 
105668.-Mag 2. Висо h0e mhthe Tocyan pqtaenhato Cobbta (Cobp.

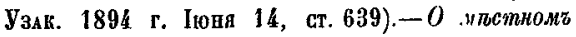
вавьдывапіи тюремною частью въ чуберніахъ Дарства Похьекало.

Государственныћ Совб̆тъ, въ Соедивеннывъ Департаментахъ Законовъ и Государственной Экономіи и въ Общемъ Собравји, разсмотрывъ предетавленіе

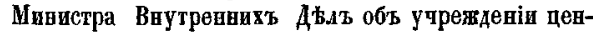
трахьвой дая губерній Парства Польскаго тюремної инепекдіи шри Варшавскомъ Генера.1ъ-Губернаторъ, въ связи съ усплөніезъ птата Варпавскаго Губернскаго Правлепія, мниніемг положсиль:

I. Относитөдьно мъстнаго завъдыванія тюремною частью въ губерніяхт Царства Польскаго, шостаноBnTb:

1) Вв составъ Губернскаго Правденія учреждается Tюремное Отавысеніе ва основаніяхъ, указанныхъ въ статьахт 1, 2, 5 и 8-12 отды. I Высочайше утвержденғаго, 21 Марта 1890 rода (6693), хнйнія Государетведнаго Совыта и нежесльдующихъ особыхъ правилъ.

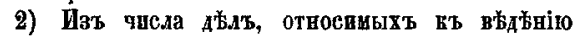
Тюремнаго Отдбдевія, подвьдомственныя, согласно дынствующих узавоневіямъ, Присутствію Губернскаго Правденія вли Губернатору, разрншаются означеннымъ Присутствіенъ ияв Губернаторомъ, по принадлежности, а вст остальныя - вхастью Губернскаго Тюремнаго Ивспектора.

3) Губерпскіні Тюремный Инспекторь состопть पленомъ Присугствія Гуйсрнскаго Правленія, во участвуетъ въ засьвданіяхт онаго только по подле-

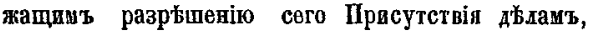
относящимся къ въатнію Тюоремнаго Отаб.енія (ст. 2).

4) Къ блпжайшей обязавности Губервскаго Tюремнаго Ивспектора относится наблюденіе за одагоустров̈ствонъ въ мбетахъ заключенія и ареста гражданскаго въдомства, а также въ псправительныхт пріютахъ и колоніяхъ, равно гакт за исподееніез' вебхъ постановзеніиі закона о порндкь содержанія и пересылвп арестантовъ. Сверхъ того, Тюремный Пнспетторъ предсъдатедьствуеть въ Попөчительствь надъ исправительнымт арестант-

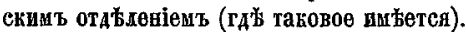

5) Ӓзопропзводство Тюремнаго Отдњвенія по нредметанъ, уназанвымъ въ статьь 2 выпеунонянутаго мнбиія Государетвеннаго Сов Бта, воздагаетея на Андогровзводштедей й пхъ Помощнивовъ, которые до примьненія настояцихъ правияь занималиеь „чооровзводствомъ по тюремной части, и на Канпеляріко Нрисутетвія Губернскаго Правленія, по прияаддежности.
6) Съ чиновъ Тюореннаго Отдјдевія, принадлежащихъ въ Эмеритахьвону Обществу Дарства Похьскаго, отчисленія въ эмердтальный капиталь дылаютея изь поднаго оклада содержанія, выqөтов'b жо въ внвалидныһ капиталь съ нихъ не провзводитея.

II. Приступшть въ губерніи Варшавской въ вынбшнем's 1894 году, въ сровт по ближайшему усмотрж-

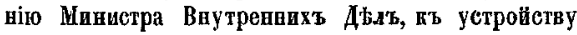
мъетнаго завъдыванія тюремною частью ва основа-

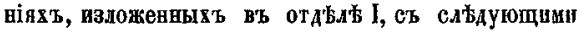
измьневіями:

1) Варшавскому Тюремному Инепектору отпускаетсл ва разъьзды по городу Варшавъ по патпеоть рублеif въ годъ.

2) Помомнипу того же Ивспевтора присвопвается годової овдадъ содержанія въ размжр’' дву хъ тысятъ рублей (въ тоаг чпсль' $1.000 \mathrm{p}$. жалованья в $1.000 \mathrm{p}$. стодовыхъ денегъ).

3) На павпелярскіе расходы Варшавскаго Губернскаго Торемнаго Ивспектора по предметамъ, прөдоетав.өвнымъ непосредственнолу его вБакинію, отпу-

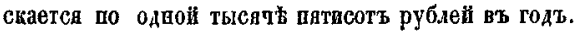

III. Расходъ по содержанію Тюремнаго Отдйлей Bapmaвсваго Губернскаго Правленін, вт разм'sр's всего семи тыснть четырехсоть рубдей въ год's (вт тожь qиель 2.500 р. ва содержаніе Губервскаго Тюреннаго Инспектора, 500 р. на вропзводство ешу разъъздныхт дөнегъ, 2.000 р. на содержаніе его Ilомощника, 900 р. на содержаніе Секретарн при Пнскектору п 1.500 р. на канцелярекіе расходы Инепектора по предметамъ, предоставденным непосредственноку его въ̆данію), вносить, начиная сь. 1 Января 1895 года, вь подыежашія подраздб̆леніп саныты Миншетеретва Внутреннихъ Д', по торемной части, а въ текущемъ году, сколько аридется по расчету со дня образованія Тюремнаго Отабленія (ота. II), покрыть на счетъ, остатковт оть уномнаут ої сжыты на 1894 годт.

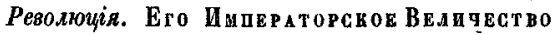

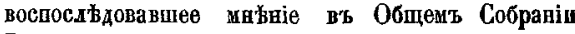
Государственнаго Совъта, относптедьно мбстнаго завъдыванія тюремного частьо въ губерніяхь Царства Польскаго, Высочайше утвердить соизводиль и поведъд псполнить. 
wi, choć tylko trzech z nich było katolikami. Pokazuje to powierzchowność rusyfikacji.

$\mathrm{W}$ tej grupie: dwóch pisało się iz dworjan, ale w rzeczywistości byli to synowie ludzi uszlachconych za służbę; jeden był szlachcicem „niepotwierdzonym przez Heroldię"; dwóch pochodziło ze stanu duchownego; jeden był synem oficera, a reszta to włościanie i mieszczanie. Urzędnicy ci posiadali co najwyżej wykształcenie średnie (czterech gimnazja oraz seminaria duchowne i nauczycielskie).

Natężenie i efektywność pracy referatu więziennego pokażemy poprzez statystykę biurową oraz opinie o poziomie organizacyjnym. Trzeba na wstępie podkreślić, że był to jeden z największych referatów pod względem ruchu spraw. W 1879 r. wicegubernator stwierdził, że ilość wychodzących stąd pism wynosiła tyle, co we wszystkich innych referatach tego wydziału łącznie i dwa razy tyle, co w innych guberniach ${ }^{13}$.

Tabela 1. Ruch spraw w referacie więziennym Rządu Gubernialnego Lubelskiego 1867-1876

\begin{tabular}{|c|c|c|c|}
\hline Rok & Zakończono & Rozpoczęto & Nie zakończono \\
\hline 1867 & 62 & 104 & 42 \\
\hline 1868 & 140 & 165 & 69 \\
\hline 1869 & 258 & 370 & 109 \\
\hline 1870 & 249 & 344 & 82 \\
\hline 1871 & 299 & 273 & 56 \\
\hline 1872 & 178 & 186 & 65 \\
\hline 1873 & 133 & 134 & 69 \\
\hline 1874 & 184 & 140 & 20 \\
\hline 1875 & 115 & 111 & 19 \\
\hline 1876 & 103 & 120 & 19 \\
\hline
\end{tabular}

Źródło: APL, RGL, sygn. WP III 1911:215a

W drugiej połowie lat 80. XIX w. okresowo większy ruch spraw wykazywał Referat IV tego wydziału - policyjny. Jednak była to tendencja przejściowa. Zresztą ruch spraw nie zawsze jest miarodajny, ponieważ sprawa mogła się ograniczać do przyjęcia podania i odpowiedzi na nie. Dlatego też chcąc zrozumieć natężenie prac, należy wziąć pod uwagę także ruch pism. Z tabeli 2 wynika, że ilość pism wchodzących do referatu więziennego była ogromna i w latach 1890-1891 zaczęła przekraczać

${ }^{13}$ APL, RGL (1867-1918), sygn. WP III 1879:47. 
10 tys. Co ciekawe, nie rosła adekwatnie ilość pism wychodzących. Może to oznaczać, że komórka osiągnęła szczyt swoich możliwości i po prostu nie była w stanie pracować bardziej intensywnie. Przy takiej dysproporcji raczej trudno zakładać, że wynikało to $\mathrm{z}$ charakteru pism wchodzących, tzn. że nie wymagały one odpowiedzi lub że wiązało się to $\mathrm{z}$ natężeniem zbierania informacji.

Tabela 2. Ruch spraw i pism w Wydziale Wojskowo-Policyjnym Rządu Gubernialnego Lubelskiego 1889-1891

\begin{tabular}{|c|c|c|c|c|c|c|c|c|}
\hline \multicolumn{9}{|c|}{ Ruch spraw w Wydziale Wojskowo-Policyjnym } \\
\hline \multirow[b]{2}{*}{ Referat } & \multirow{2}{*}{\multicolumn{2}{|c|}{$\begin{array}{c}\text { spraw } \\
\text { pozostałych } \\
\text { z } 1888 \mathrm{r} .\end{array}$}} & \multicolumn{2}{|c|}{1889} & \multicolumn{2}{|c|}{1890} & \multicolumn{2}{|c|}{1891} \\
\hline & & & $\begin{array}{l}\text { założo- } \\
\text { nych }\end{array}$ & $\begin{array}{l}\text { zakoń- } \\
\text { czonych }\end{array}$ & założonych & $\begin{array}{l}\text { zakoń- } \\
\text { czonych }\end{array}$ & założonych & $\begin{array}{l}\text { zakoń- } \\
\text { czonych }\end{array}$ \\
\hline 1 & & 4 & 63 & 40 & 53 & 46 & 109 & 112 \\
\hline 2 & & 95 & 665 & 472 & 406 & 397 & 430 & 415 \\
\hline 3 & & 23 & 434 & 257 & 337 & 298 & 523 & 533 \\
\hline 4 & & 11 & 905 & 433 & 615 & 517 & 568 & 496 \\
\hline Razem & & & 2007 & 1202 & 1411 & 1257 & 1630 & 1556 \\
\hline \multicolumn{9}{|c|}{ Ruch pism w Wydziale Wojskowo-Policyjnym } \\
\hline \multirow{2}{*}{\multicolumn{2}{|c|}{ Referat }} & \multicolumn{3}{|c|}{1889} & \multicolumn{2}{|c|}{1890} & \multicolumn{2}{|c|}{1891} \\
\hline & & \multicolumn{2}{|c|}{ wchodzących } & $\begin{array}{l}\text { wycho- } \\
\text { dzących }\end{array}$ & $\begin{array}{c}\text { wchodzą- } \\
\text { cych }\end{array}$ & $\begin{array}{l}\text { wycho- } \\
\text { dzących }\end{array}$ & $\begin{array}{c}\text { wchodzą- } \\
\text { cych }\end{array}$ & $\begin{array}{l}\text { wycho- } \\
\text { dzących }\end{array}$ \\
\hline \multicolumn{2}{|c|}{$1(\mathrm{IX})$} & \multicolumn{2}{|c|}{284} & 296 & 211 & 271 & 417 & 349 \\
\hline \multicolumn{2}{|c|}{$2(X)$} & \multicolumn{2}{|c|}{5297} & 6070 & 4994 & 5736 & 5609 & 5558 \\
\hline \multicolumn{2}{|c|}{$3(\mathrm{XI})$} & \multicolumn{2}{|c|}{9665} & 4472 & 10428 & 5815 & 11040 & 6157 \\
\hline \multicolumn{2}{|c|}{4 (XII) } & \multicolumn{2}{|c|}{2808} & 3333 & 2984 & 3192 & 3360 & 3482 \\
\hline \multicolumn{2}{|c|}{ Razem } & \multicolumn{2}{|c|}{18054} & 14171 & 18617 & 15014 & 20426 & 15546 \\
\hline
\end{tabular}

Źródło: APL, RGL (1867-1918), sygn. S 1891:156.

Referat ten prowadził sprawy dotyczące funkcjonowania nie tylko więzień, ale i aresztów, zakładów poprawczych i opiekuńczych oraz tzw. stacji etapowych. Te ostatnie służyły do przesyłania więźniów. Nadzorowanie systemu tych stacji wiązało się również z wysyłaniem na zesłanie i wydalaniem obcokrajowców. Strażnicy aresztów policyjnych w powiatach przygranicznych zajmowali się ponadto konwojowaniem zatrzymanych obcokrajowców (najczęściej za nielegalne przedłużenie pobytu, ale także na podstawie wyroków sądów i decyzji administracyjnych) do przejść granicznych, jak np. w Podbełżcu w powiecie tomaszowskim, 
gdzie wyznaczono punkty wymiany (передаточные пункты) $)^{14}$. Operacja wydalenia obcokrajowca była finansowana $z$ budżetów aresztów policyjnych. Ponadto $\mathrm{w}$ referacie zbierano informacje o podopiecznych tych instytucji, nawet po ich zwolnieniu lub ucieczce. Tutaj wreszcie koncentrowało się zarządzanie personelem więziennictwa ${ }^{15}$. Do kwestii wymagających większej uwagi zaliczano ściąganie kar pieniężnych, które zasilały fundusz więzienny ${ }^{16}$. Ogólnie rzecz biorąc, poza stroną merytoryczną szczególnie skrupulatna była strona finansowa, a co za tym idzie rachunkowa, zarządzania więziennictwem.

Po rewolucji 1905 r. zwrócono baczniejszą uwagę na funkcjonowanie systemu. Oczywiście rozpoczęto od rewizji. W 1909 r. wicegubernator lubelski prosił o informacje dotyczące ruchu spraw ${ }^{17}$, więc buchalter Powalczuk raportował, że w referacie III (więziennym) w okresie 1 I 1908 1 I 1909 r.:

1. Zostało niezałatwionych do 1 I 1908 r. spraw - 602, pism - 364 .

2. Przybyło w $1908 \mathrm{r}$. spraw -433 , pism -9627 .

3. Załatwiono w $1908 \mathrm{r}$. spraw -608 , pism -9571

4. Zostało 1 I 1909 r. spraw -427 , pism -420 .

Dla porównania referent Martynowskij sprawozdał, że w IV referacie:

1. Zostało niezałatwionych do 1 I 1908 r. spraw - 136, pism - 249.

2. Przybyło w $1908 \mathrm{r}$. spraw -804 , pism -4956 .

3. Załatwiono w $1908 \mathrm{r}$.

4. Zostało 1 I 1909 r. spraw -776 , pism -5234 spraw $-164^{18}$, pism $-71^{19}$.

Kiedy porównamy te dane z zestawieniem za kilka kolejnych lat, możemy, po pierwsze, zauważyć, że się różnią, a po drugie i ważniejsze, że występuje stała tendencja rosnąca. Coraz więcej spraw otwierano, a coraz mniej zamykano, co w efekcie powodowało zwiększenie się spraw niezałatwionych. Gdy na początku roku 1909 odnotowano 840 niezałatwionych spraw z lat poprzednich, musiało to oznaczać paraliż zarządzania więziennictwem w guberni lubelskiej. Kierujący referatem Powalczuk nie widział innego wyjścia, jak ucieczka celem uniknięcia odpowiedzialności.

Rewizja referatu więziennego w 1911 r. przyniosła następujące uwagi dotyczące jego działalności:

${ }^{14}$ APL, RGL (1867-1918), sygn. WP III 1895:110, knlb., Raport naczelnika powiatu tomaszowskiego do gubernatora lubelskiego z 4 XII $1895 \mathrm{r}$.

${ }^{15}$ APL, RGL (1867-1918(, sygn. WP III 1911:215a.

${ }^{16}$ Rocznie ściągano z mieszkańców guberni lubelskiej ok. 11 tys. rub. kar.

${ }^{17}$ APL, RGL (1867-1918), sygn. K 1909:18.

${ }^{18}$ W tym z 1903 r. - 3, 1905 r. - 1, 1906 r. - 2, 1907 r. - 14, 1908 r. - 144 sprawy.

${ }^{19}$ APL, RGL (1867-1918), sygn. K 1909:18. 
- Referatem zarządzał buchalter Traulinskij od VII 1909 r. po ucieczce Powalczuka, który pozostawił referat w stanie chaotycznym.

- Ma on dwóch młodszych pomocników referenta i trzech pracowników kancelaryjnych.

- Ze względu na zróżnicowanie korespondencji i złożoność rachunkowości referat więzienny jest jednym $\mathrm{z}$ większych w rządzie gubernialnym.

- Należą do niego:

1) Ogólny nadzór nad więzieniami, śledczymi i policyjnymi aresztami i stacjami etapowymi.

2) Zapewnienie miejscom odosobnienia ciepła i oświetlenia; dostarczenie więźniom produktów aprowizacyjnych; przygotowanie odzieży, bielizny, obuwia i pościeli dla aresztantów i mundurów dla dozorców; wyposażenie więzień, aresztów i stacji etapowych $\mathrm{w}$ różne niezbędne sprzęty.

3) Wypełnianie sądowych wyroków skazujących na przekazanie do aresztanckich oddziałów poprawczych i na zesłanie na prace katorżnicze.

4) Przekazanie dobrze sprawiających się aresztantów do oddziałów poprawczych i skracanie okresu prac katorżniczych tym osadzonym, którzy przebywają w więzieniach miejscowych.

5) Wysyłanie do innych guberni pod nadzór policji osób zgodnie z rozporządzeniami władz administracyjnych.

6) Wysyłanie do wschodnich guberni Cesarstwa zagranicznych dezerterów.

7) Wydalanie za granicę obcokrajowców po odbyciu kary związanej z pozbawieniem wszelkich specjalnych praw i przywilejów zgodnie $\mathrm{z}$ wyrokiem sądowym, a także obcokrajowców zdemaskowanych na szkodliwej działalności, według zarządzeń władz administracyjnych.

8) Poddawanie 4-letniemu nadzorowi policyjnemu więźniów, którzy odbyli wyrok $w$ aresztanckich oddziałach poprawczych.

9) Poszukiwanie i zatrzymywanie aresztantów zbiegłych z miejsc odosobnienia i z transportu.

10) Budowa nowych aresztów oraz kapitalne i zwykłe remonty celem utrzymania placówek w porządnym stanie.

11) Przesyłanie aresztantów trybem etapowym i liniami pozaetapowymi; organizowanie ludzi zajmujących się tym oraz koniecznych środków i kontroli, a także pieniężnej sprawozdawczości.

12) Obliczanie i wydatkowanie kredytów na potrzeby więzienne.

13) Asygnowanie wynagrodzeń mieszkańcom guberni za podwody dostarczone do przewozu chorych więźniów. 
14) Dozór nad terminowym wpływem kar pieniężnych do ogólnego funduszu więziennego i do specjalnego funduszu przeznaczonego na budowę pomieszczeń więziennych, zakładanych przez sądy okręgowe, pokoju, gminne i przez władze administracyjne ${ }^{20}$.

Do rewizji dołączono statystykę biurową spraw i pism za kilka poprzednich lat.

Tabela 3. Ruch spraw w referacie więziennym Rządu Gubernialnego Lubelskiego 1906-1910

\begin{tabular}{|c|c|c|c|c|}
\hline & Otworzono nowych & Zostało starych & Zakończono & Zostało \\
\hline 1906 & 395 & 480 & 307 & 568 \\
\hline 1907 & 440 & 568 & 425 & 583 \\
\hline 1908 & 436 & 583 & 179 & 840 \\
\hline 1909 & 450 & 840 & $?$ & $?$ \\
\hline \multicolumn{5}{|c|}{ Na dzień 1 I 1909 r. zostało z lat poprzednich 840 spraw niezałatwionych } \\
\hline \multicolumn{6}{|c|}{ Ruch pism według dziennika pism wchodzących } \\
\hline \multicolumn{6}{|c|}{ Sprawy } & 1906 & 1907 & 1908 & 1909 \\
\hline Wpłynęło & 6356 & 7654 & 9627 & 8497 \\
\hline Załatwiono & 7563 & 7565 & 8959 & 5399 \\
\hline Nie załatwiono & 33 & 89 & 666 & 3098 \\
\hline
\end{tabular}

Źródło: APL, RGL, sygn. WP III 1911:215a

W 1914 r. skład III referatu wydziału wojskowo-policyjnego wyglądał następująco: buchalter (Stiepan Pietrowicz Lipowskij do 1 II 1914 r.), trzech młodszych pomocników referenta, jeden urzędnik do pism. Wtedy to podsumowano zakres spraw, dzieląc je na cztery grupy:

1. Dotyczące budowy, remontu, najmu i utrzymania miejsc odosobnienia.

2. Dotyczące składu osobowego służących w referatach i miejscach odosobnienia w lubelskiej guberni.

3. Dotyczące nadzoru i utrzymania aresztantów.

4. Dotyczące dezerterów z obcych wojsk.

Spraw niezakończonych zostało do 1 I 1914 r. - 420. Zakończono (1 I 1914-31 III 1914) - 67. Przykładowe uwagi o kilku sprawach: „Straszna niedbałość, zwłoka i brak nadzoru nad referatem"; "Jawnie radca nie spieszy się z wykonaniem rezolucji gubernatora"; "W sprawie jest tylko brudnopis, z którego nic nie wynika”; "W czasie rewizji okazało się, że przedstawiono radcy do podpisu 216 pism, które nie mogły zostać zaliczone jako załatwione $\mathrm{w}$ toku całego czasu rewizji. Biorąc pod uwagę, że

${ }^{20}$ APL, RGL (1867-1918), sygn. WP III 1911:215a. 
w ciągu dnia powinno być załatwianych 30 pism, znajduję, że trzymanie niepodpisanych 216 pism stanowi całkiem dużą liczbę. Widzę w takiej sytuacji wielką nieporadność ze strony radcy”; „Księgi kontrolne kar i buchalteryjne księgi w porządku".

Po tej rewizji sfomułowano następujące wnioski:

Zrewidowawszy III referat wojskowo-policyjnego wydziału, doszedłem do wniosku, że radca nie ma nad nim żadnego nadzoru. Prowadzenie spraw w petni powierzono referentowi, którego dziatalność znajdować się powinna pod kontrola radcy. Dopóki był referentem Bojko, człowiek niemrawy i nieuważny, sprawy leżaty bez ruchu, po przystapieniu do pracy nowego referenta Lipowskiego pojawiaja się w niektórych sprawach bruliony [brudnopisy] powtórnych ponagleń $i$ żadań zatatwienia. Skutkiem takiego stosunku radcy w referacie jest duża liczba spraw nieskończonych, takiego rodzaju, które wymagają zakończenia nie później niż do 1 II każdego roku - to sprawy o nałożenie kar zarówno administracyjna, jak i droga sadowa. Zauważono także brak nadzoru nad ekspedytura, podpisane pisma wysyła się przez tydzień albo i później, po podpisaniu. W III referacie zostało niezakończonych spraw do 1 I 1914 r. - 420. Zakończono (1 I $1914-31$ III 1914) - 67. Biorac pod uwagę, że w ciagu dnia powinno być załatwianych 30 pism, znajduję, że 216 niepodpisanych pism stanowi catkiem duża liczbę. Widze w tej okoliczności wielka nieporadność ze strony radcy ${ }^{21}$.

\section{ZARZĄDY POWIATOWE}

Zgodnie z ustawą z 19/31 XII 1866 r. ${ }^{22}$ powiatami miały kierować ciała kolegialne - zarządy przy pomocy urzędu i samodzielnych urzędników. Zarząd, pod przewodnictwem naczelnika, składał się z dwóch jego pomocników jako członków stałych. Na posiedzenia byli też wzywani inni urzędnicy $\mathrm{w}$ charakterze specjalistów. Tak więc w skład prezydium zarządu powiatowego mogli wchodzić: lekarz powiatowy, budowniczy lub inżynier powiatowy, radca ubezpieczeń, członkowie komitetów drogowych i weterynarz powiatowy. Zarząd kolegialnie rozstrzygał ponad dwadzieścia kategorii spraw administracyjnych ściśle określonych w ustawie, jak np. kontrola rachunków więzien. ${ }^{23}$

\footnotetext{
${ }^{21}$ APL, RGL (1867-1918), sygn. K 1914:11.

${ }^{22}$ DPKP, t. 66, Ustawa o zarządzie gubernialnym...

${ }^{23} \mathrm{Na}$ posiedzeniach kolegium zajmowano się następującymi sprawami: a) przyjmowanie przysięgi od cudzoziemców na wierność poddaństwa, b) rozpatrywanie zażaleń na nieprawne działania urzędników i oficjalistów oraz wyroków sądowych zapadłych w ich sprawach, c) wynajmowanie domów i zakup mebli dla urzędu powiatowego oraz wynajmowanie pomieszczeń dla lazaretów wojskowych i aresztów, d) kontrola stanu kas
} 
Mimo licznych kompetencji decyzyjnych prezydium to naczelnik powiatowy był rzeczywistym zarządcą powiatu, co stanowił odpowiedni artykuł ustawy ${ }^{24}$. Jego kompetencje, tym razem szczegółowo, określał ukaz wprowadzony 19/31 XII 1866 r. Jak i poprzednio, nałożono na niego pieczę „nad ścisłym wykonywaniem wiernopoddańczych obowiązków, praw i rozporządzeń rządu nad zachowaniem ogólnego porządku, bezpieczeństwa i ładu, tudzież nad zupełną nietykalnością praw własności". W tym celu był uprawniony do kontrolowania instytucji rządowych, $\mathrm{w}$ tym trzy razy $\mathrm{w}$ roku miał rewidować kasy miejskie oraz wizytować (rewidować) więzienia, areszty i szpitale. Podlegała mu także straż ziemska, a w razie potrzeby mógł wzywać pomoc wojska ${ }^{25}$.

Naczelnik i zarząd swoje kompetencje realizowali przez zaplecze urzędowe i tu należy zwrócić uwagę na wydział wojskowo-policyjny kierowany przez pomocnika naczelnika ds. wojskowo-policyjnych. W $1874 \mathrm{r}$. dział wojskowy tego wydziału został wyodrębniony w powiatowy urząd ds. powinności wojskowej. Pomocnik naczelnika powiatu ds. policyjnych był jednocześnie naczelnikiem straży ziemskiej oraz powierzono mu kontrolowanie ksiąg ludności, chociaż zarządzanie nimi skoncentrowano w wydziale ogólnym ${ }^{26}$. Wydział ten zajmował się m.in. - choć raczej pozostawało to na uboczu jego działalności - zarządem więzieniami oraz sprawami policji medycznej i gospodarczej, celnymi i granicznymi. Tutaj prowadzone były sprawy tajne ${ }^{27}$.

okręgowych, e) sporządzanie projektów etatów, dochodów i wydatków miast i instytucji rządowych, f) układanie rozpisów podatków skarbowych, gruntowych i opłat gminnych składki transportowej i kwaterunkowej, od ubezpieczeń itp., g) wypłaty kosztów podróży i diet urzędnikom, h) umorzenie podatków skarbowych i składek, i) organizowanie licytacji na budowę, dostawę i dzierżawę wszelkich realności, j) zakup żywności dla więzień - DPKP, t. 66, Ustawa o zarządzie gubernialnym..., art. 106.

${ }^{24} D P K P$, t. 66, Ustawa o zarządzie gubernialnym..., art. 87 - „Naczelnik powiatu zarządza bezpośrednio, pod zwierzchnictwem gubernatora i rządu gubernialnego, powierzonym mu powiatem, ze wszystkimi wchodzącymi w jego skład miastami, miasteczkami, gminami, folwarkami i gruntami".

${ }^{25}$ DPKP, t. 66, Ustawa o zarządzie gubernialnym..., art. 92-93.

${ }^{26} \mathrm{~W}$ ogólnym wydziale są drugie egzemplarze ksiąg народонаселения, ale faktycznie nie ma ich nigdy w Zarządzie Powiatowym w pełnym składzie i zwykle блуждают po powiecie przez większość roku: z powodu braku w Zarządzie Powiatowym specjalnego urzędnika do prowadzenia i korygowania ksiąg ludności te ostatnie na początku każdego roku rozsyłane są do gmin celem wnoszenia zapisów i uwag o zmianach i wracają do Zarządu Powiatowego jedynie w końcu roku, a następnie po 2-3 miesiącach znów są wysyłane do gmin, w następstwie czego drugimi egzemplarzami ksiąg Zarząd Powiatowy dysponować nie może i niezniszczalność tych ksiąg okazuje się niezabezpieczona - Archiwum Państwowe w Łodzi, Zarząd Powiatowy Skierniewicki, sygn. 3, p. 3.

${ }^{27} D P K P$, t. 66, Ustawa o zarządzie gubernialnym..., art. 117. 
Podsumowując, należy zaakcentować kwestie, które wpływały na operatywność zarządzania więziennictwem. Przede wszystkim warto podkreślić nieracjonalny priorytet rusyfikacyjny, obniżający wymagania wobec personelu. Z pewnością można było znaleźć urzędników polskich lepiej wykształconych i lepiej zorientowanych w prawie i praktyce.

Stałym mankamentem była niedostateczna liczba etatów i nadmierna komplikacja procedur urzędowych. Istotne dla zarządzania było podwójne podporządkowanie więziennictwa i współpraca $\mathrm{z}$ wymiarem sprawiedliwości (np. przy śledztwach). W warunkach rosyjskich zespolenie to wywoływało konflikty, szczególnie między MSW a resortem finansów, ale i sprawiedliwości. Ogólnie trzeba jednak podkreślić pozytywny charakter takiego podporządkowania.

Do innych zalet należy zaliczyć niewłączenie zarządu więziennictwa do samodzielnych kompetencji gubernatora (realizowanych przez kancelarię gubernatora $z$ ominięciem rządu gubernialnego) i tym samym mniejsze upolitycznienie kwestii oraz decentralizację zarządzania.

\section{BIBLIOGRAFIA:}

Walczak S., Prawo penitencjarne. Zarys systemu, Warszawa 1972.

Demidowicz T., Z dziejów polskiej myśli penitencjarnej. Julian Ursyn Niemcewicz (1758-1841) i jego poglady na temat więziennictwa, „Przegląd Więziennictwa Polskiego” 2005, nr 49.

Czołgoszewski J., Więziennictwo Księstwa Warszawskiego, „Przegląd Więziennictwa Polskiego" 2010, nr 69.

Osoba A., Z dziejów polskiej dziewiętnastowiecznej myśli penitencjarnej, „Przegląd Więziennictwa Polskiego" 2001, nr 32-33.

Гернет М. М., История цзарской тюрмы, Moskwa 1952.

\section{ABSTRACT:}

The penitentiary system in the nineteenth century was one of the indicators of the progress of civilization state, however in the Polish Kingdom after the January Uprising was introduced Russian standards. An additional element of worsening quality of this resort was the emphasis on the Russification of staff. The article analyzes the role of different authorities in managing the penitentiary system and its components. The key role have prisons unit of the Gubernyas Government, which was part of the executive apparatus this collegial authorities. Only in the Warsaw gubernya was appointed the prison department as the realization of penitentiary inspection.

Key words: penitentiary system, the Kingdom of Poland, Russian Empire, Lublin Governorate, the province government, the board of poviat 


\section{NOTA O AUTORZE:}

Artur Górak - historyk i archiwista zajmujący się głównie dziejami biurokracji w Polsce i Europie Wschodniej XIX i XX wieku, przez co rozumie dyplomatykę, historię administracji i kancelarii. Organizator Międzynarodowych Sympozjów Dziejów Biurokracji, redaktor „Wschodniego Rocznika Humanistycznego", e-mail: artur.gorak@poczta.umcs. lublin.pl. 